Gut, 1984, 25, 32-40

\title{
Intestinal lymphocyte subpopulations in inflammatory bowel disease: an analysis by immunohistological and cell isolation techniques
}

\author{
W S SELBY, G JANOSSY, M BOFILL, AND D P JEWELL \\ From the Gastroenterology Unit, John Radcliffe Hospital, Oxford, and Department of Immunology, Royal \\ Free Hospital School of Medicine, London
}

SUMMARY Lymphocyte subpopulations in the intestinal mucosa of patients with ulcerative colitis or Crohn's disease have been studied using a double marker immunofluorescence technique. Analysis of tissue sections revealed that the majority of intraepithelial lymphocytes (IEL) were T cells $\left(\mathrm{Hle}-1^{+} \mathrm{HuTLA}^{+} \mathrm{UCHT}^{+}\right.$). Of these, over $80 \%$ were of suppressor-cytotoxic phenotype $\left(\mathrm{OKT}^{+}: 83 \pm 10 \cdot 2 \%\right)$ with a small population of helper type IEL $\left(\mathrm{OKT} 4^{+}\right)$. Only one third of $\mathrm{OKT}^{+}{ }^{+}$IEL reacted with the $\mathrm{T}$ cell antibody, anti-Leu-1. IEL were also $\mathrm{Tac}^{-}, \mathrm{C} 3 \mathrm{~b}$-receptor ${ }^{-}$ $\left(\mathrm{C} 3 \mathrm{RT} 05^{-}\right)$, and $\mathrm{Ig}^{-}$. Within the lamina propria, OKT4 ${ }^{+} \mathrm{T}$ cells predominated (ulcerative colitis $64 \pm 6.0 \%$; Crohn's disease $63 \pm 6.0 \%$ ). Less than half of the smaller $\mathrm{OKT}^{+}$population in the lamina propria was Leu- $1^{+}$. These finding did not differ from those seen in histologically normal tissues from controls, and are similar to those reported in the small intestine. Mononuclear cells were also isolated from the intestinal lamina propria using an enzymatic technique. The majority of lymphocytes obtained were $\mathrm{T}$ cells $\left(\mathrm{OKT}^{+}\right)$, with populations of $\mathrm{OKT} 4^{+}$and $\mathrm{OKT} 8^{+}$cells. Comparison of the ratio of $\mathrm{OKT}^{+}{ }^{+}$to $\mathrm{OKT}^{+}{ }^{+}$lymphocytes determined by immunohistological analysis with that obtained in mucosal isolates, however, suggested that the isolation procedure may deplete $\mathrm{OKT}^{+}$cells. These findings indicate that an imbalance of mucosal immunoregulatory $\mathrm{T}$ cells, as defined by monoclonal antibodies, does not occur in inflammatory bowel disease. They also emphasise that functional studies of isolated intestinal mucosal cells should be combined with morphological studies of cell populations in situ.

Although the pathogenesis of inflammatory bowel disease is unknown, immunological factors, both humoral and cell mediated, appear to be involved. ${ }^{1}$ Cellular immunity may be impaired, based on findings such as hyporesponsiveness to skin testing and impaired responsiveness of peripheral blood lymphocytes to non-specific mitogens or alloantigens. These findings, however, have not been confirmed by all workers. Suppressor function of peripheral blood lymphocytes is also impaired. ${ }^{23} \mathrm{~A}$ recent study, using monoclonal antibodies, has shown that, although there is a reduction in the number of peripheral blood lymphocytes in patients with ulcerative colitis or Crohn's disease, the proportions of $\mathrm{T}$ lymphocytes $\left(\mathrm{OKT}^{+}\right)$, helper type

Address for correspondence: Dr W S Selby, Gastroenterology Unit, Radcliffe Infirmary, Woodstock Road, Oxford OX2 6HE

Received for publication 15 March 1983
T lymphocytes $\left(\mathrm{OKT}_{4}^{+}\right)$, and suppressor-cytotoxic type $\mathrm{T}$ lymphocytes $\left(\mathrm{OKT}^{+}\right)$are not altered. ${ }^{4}$ These finding are consistent with sequestration of lymphocytes into the involved intestinal mucosa, where the numbers of lymphocytes, both $T$ cells and $B$ cells, are indeed increased. ${ }^{56}$

Within normal intestinal mucosa, the majority of intraepithelial lymphocytes are $\mathrm{T}$ lymphocytes of suppressor-cytotoxic type $\left(\mathrm{OKT}^{+}\right){ }^{7}$ In the lamina propria, $\mathrm{OKT}_{4}{ }^{+}$, helper type $\mathrm{T}$ cells predominate. $^{78}$ The distribution of $\mathrm{T}$ lymphocyte subsets in intestinal mucosa affected by inflammatory bowel disease is unknown.

The aim of this study was to examine the proportions of immunoregulatory $\mathrm{T}$ lymphocytes, as defined by monoclonal antibodies, in the intestinal mucosa of patients with ulcerative colitis or Crohn's disease, using an immunohistological technique, and to compare the findings with those in histologically 
normal intestine. In addition, mononuclear cells have been isolated from the intestinal lamina propria, using an enzymatic technique ${ }^{9}{ }^{10}$ and the $\mathrm{T}$ cell populations analysed.

\section{Methods}

\section{SUBJECTS}

TISSUE SECTIONS

Three groups of subjects were studied: (1) 15 patients with ulcerative colitis (seven men, eight women), with a mean age of 40.9 years (range 21-62 years). Thirteen of these patients had active disease as determined by clinical criteria and histological findings. Nine patients were receiving sulphasalazine and six corticosteroids. (2) Thirteen patients with Crohn's disease (six men, seven women), with a mean age of $34 \cdot 8$ years (range 17-50 years). Nine of these patients had colitis, three ileocolitis, and one ileal disease alone. In all but two patients, the disease was clinically and histologically active. In one patient, involved and non-involved mucosa were studied separately. Three patients were taking sulphasalazine and five corticosteroids. (3) Nine control subjects (six men, three women) undergoing colectomy for colonic neoplasia or colonoscopy for exclusion of colonic polyps. The mean age of these patients was 56.2 years (range 25-72 years).

Biopsies were obtained at the time of surgery or at colonoscopy (Fig. 1a,b). The specimens were orientated on cork, covered with OCT compound (Ames $\mathrm{Co}$ ) and frozen in isopentane suspended over liquid nitrogen until used.

\section{IMMUNOFLUORESCENCE}

Five micron sections were cut on a cryostat, air dried, fixed in absolute ethanol for 10 minutes, and washed in phosphate buffered saline (PBS). For double labelling with monoclonal antibodies, sections were fixed in chloroform:acetone and lyophilised before staining or storage. ${ }^{11}$

Antibodies were applied to the sections for 30 minutes, followed by washing for 30 minutes. Second layer, and where appropriate third layer, antisera were applied for a similar period. Slides were mounted in $50 \%$ glycerol in PBS.

\section{ANTIBODIES}

Intraepithelial lymphocytes were identified using a monoclonal antibody (2D1) which reacts with human leucocyte antigen (HLe-1). ${ }^{12} \mathrm{~T}$ lymphocytes were shown using a specific rabbit antiserum ( $R$ anti-HuTLA) $)^{7}$ as well as by the monoclonal antibodies UCHT1, which has similar reactivity to OKT3, and which detects all peripheral blood T
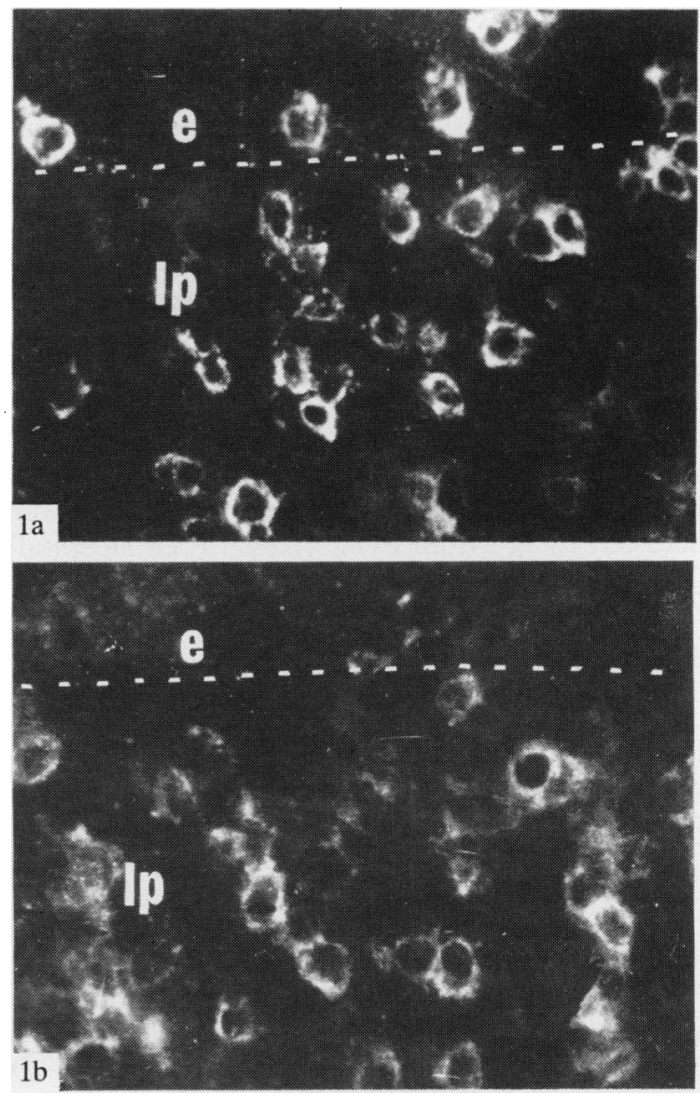

Fig. 1 Colonic biopsy from a patient with active Crohn's colitis. (a) OKT8 (TRITC); (b) OKT4 (FITC). Within epithelium (e), the IEL are $O K T 8^{+}$. Lamina propria (lp) contains $\mathrm{OKT}^{+}$cells and $\mathrm{OKT}^{+}$cells. Broken line represents basement membrane.

cells ${ }^{13}$ and anti-Leu-1, which defines a 67000 dalton antigen on T lymphocytes and thymocytes. ${ }^{14}$ Helper type $\mathrm{T}$ lymphocytes and suppressor-cytotoxic type $\mathrm{T}$ lymphocytes were identified using the monoclonal antibodies OKT4 and OKT8, respectively. ${ }^{15}$ AntiLeu-1 and OKT4 were conjugated with biotin ${ }^{16}$ and were used in double labelling studies with OKT8 conjugated with arsanilic acid (OKT8 ARS). ${ }^{11} 16$

HLA-DR antigens were detected using an antiserum raised in chickens against $p 28,33$ antigens (C anti-Ia). ${ }^{7}$ Anti-Tac, which reacts with an antigen expressed by $\mathrm{T}$ lymphocytes following stimulation in vitro, was used to detect 'activated' T cells. ${ }^{17}$ Cells with receptor for $\mathrm{C} 3 \mathrm{~b}$ component of complement were detected using the antibody C3RT05. ${ }^{18}$ Controls were performed using NA1/34, a monoclonal antibody to human thymocyte antigen, which 
is unreactive with intestinal tissue, ${ }^{7}$ and using normal rabbit and chicken serum. Immunoglobulins (Ig) were detected using antisera to IgA, conjugated with tetramethylrhodamine isothiocyanate (TRITC), IgM, labelled with fluorescein isothiocyanate (FITC), IgG (FITC), kappa light chains (FITC), and lambda light chains (TRITC). ${ }^{8}$

Monoclonal antibodies applied alone or in combination with heterologous antisera were used in indirect immunofluorescence with goat antimouse Ig antiserum, conjugated with FITC (Nordic). $R$ anti-HuTLA was used with swine anti-rabbit Ig TRITC (Dako) and C anti-Ia with sheep anti-chicken Ig TRITC (Royal Free Hospital). Antibodies conjugated with biotin were detected using avidin FITC (Royal Free Hospital). OKT8 ARS was used in a triple layer system, with rabbit anti-arsanilate as the second layer, and swine anti-rabbit Ig TRITC as the third.

The following combinations of antisera were used: (1) 2D1 and R anti-HuTLA, to identify T IEL; (2) R anti-HuTLA and OKT8 to determine the proportion of $\mathrm{T}$ IEL that were of suppressorcytotoxic phenotype; (3) OKT8 and Leu-1; (4) OKT4 and OKT8; and (5) R anti-HuTLA or UCHT1 in combination with C anti-Ia.

Sections were examined under a Zeiss fluorescence microscope with selective filters for FITC (green) and TRITC (red). Two to three sections of each biopsy were examined (10-20 high power fields) with, in most cases, at least 100-200 IEL and LPL being counted.

\section{MUCOSAL CELL ISOLATION}

SUBJECTS

Intestinal tissue was obtained at the time of resection in three groups of patients: (1) five patients with carcinoma of the colon, one with polyposis, and one with Hirschprung's disease (six men, one woman; mean age 56 years, range 16-79 years). Macroscopically normal tissue was taken in each case. (2) Five patients with active ulcerative colitis (four men, one woman; mean age 55 years, range 40-65 years). (3) Seven patients with active Crohn's disease (six with colitis, one with ileitis; one man, five women; mean age 30 years, range 21-41 years). In nine of these subjects, tissue sections taken from the resected intestine were also examined.

\section{GUT MUCOSAL CELLS}

An enzymatic technique was used to isolate mononuclear cells from the lamina propria. ${ }^{910}$ Briefly, the mucosa was washed in $1 \mathrm{mM}$ dithiothreitol in calcium and magnesium free Hanks balanced salt solution for 15 minutes, then in EDTA, until epithelial cells were removed, and finally incubated overnight in RPMI 1640 containing $20 \mathrm{U} / \mathrm{ml}$ purified collagenase (CLSPA, Worthington Enzymes) as well as $10 \%$ heat inactivated fetal calf serum, penicillin $(100 \mathrm{U} / \mathrm{ml})$, gentamicin $(50 \mu \mathrm{g} / \mathrm{ml})$ and Hepes buffer $(25 \mathrm{mM})$. After this, the mononuclear cells were washed and spun on Ficoll hypaque at $400 \mathrm{~g}$ for 30 minutes. At each stage of the procedure, cells were counted and their viabilities determined using $0 \cdot 1 \%$ trypan blue.

\section{IMMUNOFLUORESCENCE}

Immunofluorescence was performed on the cell suspensions as previously described, using OKT3, OKT4, and OKT8 in combination with antiserum to HLA-DR antigens. ${ }^{4}$ Antiserum to human immunoglobulin and, in several cases, anti-Tac and OKT1, were also used.

In four experiments, $\mathrm{T}$ lymphocyte subpopulations in the peripheral blood were studied before and after treatment with EDTA and overnight incubation with collagenase.

\section{MITOGEN STIMULATION}

Gut mucosal cells and PBL from five patients (two controls, two with Crohn's disease, and one with ulcerative colitis) were stimulated with phytohaemagglutinin (PHA) and/or concanavalin A (Con A). Briefly, $10^{6}$ cells in $1 \mathrm{ml}$ of RPMI 1640 containing $10 \%$ heat inactivated fetal calf serum and antibiotics were placed in wells of tissue culture plates, to which were added either PHA $(10 \mu \mathrm{g} / \mathrm{ml})$, Con A $(5 \mu \mathrm{g} / \mathrm{ml})$, or medium. The optimal concentrations of mitogens had been determined from previous experiments. After incubation for three days in 5\% $\mathrm{CO}_{2}-95 \%$ air at $37^{\circ} \mathrm{C}$, the cells were harvested, washed, and immunofluorescence performed using anti-Tac and OKT3/C anti-Ia combination. Controls were performed as outlined above.

\section{QUANTITATION}

Fluorescence microscopy was performed as described above. Lymphocytes in the gut mucosal cell populations were identified by their morphology, and macrophages by their size, granularity, and expression of HLA-DR antigens. A small proportion of plasma cells and of granulocytes was also seen and these were excluded from quantitation.

STATISTICAL ANALYSIS

Results were analysed using Wilcoxon's rank sum test. 
Results

TISSUE SECTIONS

Over $80 \%$ of intraepithelial lymphocytes in the intestinal epithelium of patients with ulcerative colitis or Crohn's disease were $\mathrm{HuTLA}^{+}$, and of these, the majority were OKT ${ }^{+}$(Table 1$) .{ }^{7}$ Double labelling studies confirmed the predominance of $\mathrm{OKT}^{+} \mathrm{OKT}^{-}$lymphocytes within the epithelium, with a smaller proportion of $\mathrm{OKT} 4^{+} \mathrm{OKT} 8^{-}$, helper type cells. No double labelled $\mathrm{OKT}^{+} \mathrm{OKT}^{+}$ intraepithelial lymphocytes were seen. Examination of serial sections revealed that intraepithelial lymphocytes were also $\mathrm{UCHT}^{+}{ }^{+}$. Only a minority of $\mathrm{OKT}^{+}$intraepithelial lymphocytes $(33 \%$ in ulcerative colitis and $37 \%$ in Crohn's disease), however, showed detectable reactivity with antiLeu-1. The expression of Leu-1 on these cells was weak compared with that on $\mathrm{OKT}^{-}$Leu- $^{+}$ $\left(\mathrm{OKT}^{+}\right)$cells and on $\mathrm{OKT}^{+}$Leu- $^{+}$cells in lymphoid follicles of the lamina propria. These findings did not differ from those seen in the epithelium of control subjects.

Neither membrane or cytoplasmic immunoglobulin $\left(\mathrm{Ig}^{-}\right)$nor C3b receptor (C3RT05 ${ }^{-}$) were identified on intraepithelial lymphocytes in patients or in controls. Normal intraepithelial lymphocytes rarely expressed HLA-DR antigens, and were also $\mathrm{Tac}^{-}$. The colonic epithelium in most patients with active ulcerative colitis or Crohn's disease, however, showed variable expression of HLA-DR antigens. Thus, it was not possible to determine the expression of these antigens on intraepithelial lymphocytes. Nevertheless, intraepithelial lymphocytes were again $\mathrm{Tac}^{-}$.

In active inflammatory bowel disease, the lamina propria was infiltrated with $\mathrm{HuTLA}^{+} \mathrm{UCHT}^{+}{ }^{+} \mathrm{T}$ cells. The majority of these cells (approximately two thirds) were $\mathrm{Leu}_{-1}{ }^{+} \mathrm{OKT}^{+}{ }^{+}, \mathrm{OKT}^{-}$, helper type $\mathrm{T}$ cells, and this did not differ from normal (Table 3 ). This was true both in superficial and deeper parts of the mucosa. As in the epithelium, just over one third of the smaller $\mathrm{OKT} 8^{+}$population was Leu- ${ }^{+}$. $\mathrm{Tac}^{+}$cells were identified in some sections from patients with inflammatory bowel disease, but were infrequent.

In several specimens of normal colonic mucosa, lymphoid follicles were present in the lamina propria. These consisted of a central area of B cells $\left(\mathrm{Ig}^{+} \mathrm{HLA}^{-D R}{ }^{+} \mathrm{C} 3 \mathrm{RTO5}^{+}\right)$with a surrounding zone of $\mathrm{T}$ lymphocytes. The proportion of OKT4 $4^{+}$cells was three to four times greater than that of $\mathrm{OKT}^{+}$ cells in this $\mathrm{T}$ cell zone. Scattered $\mathrm{OKT}^{+}{ }^{+}$cells were also seen in the $\mathrm{B}$ cell area. Of the $\mathrm{OKT}^{+}$cells, the majority showed expression of Leu-1. HLA-DR ${ }^{+}$, interdigitating cells were also present in the $\mathrm{T}$ cell area.

Lymphoid follicles with germinal centres were seen in several patients with ulcerative colitis or Crohn's disease. The distribution of $T$ and $B$ lymphocytes in these follicles was similar to that seen in normal follicles. There was no alteration in the proportions of $\mathrm{T}$ cell subsets in the $\mathrm{T}$ cell zone of the follicles.

The findings in patients with inflammatory bowel disease were not affected by the form of treatment being received, nor by the severity of the disease. In inactive disease, and in non-involved mucosa, the proportions of $\mathrm{T}$ lymphocytes in the epithelium or in the lamina propria were not different from those seen in active disease or in controls. Epithelial expression of HLA-DR antigens, however, was rarely seen.

\section{GUT MUCOSAL CELLS}

The yield of cells isolated from the intestinal mucosa of patients with inflammatory bowel disease was significantly greater than that from normal mucosa (Table 2). This was true of the crude yield, obtained after digestion with collagenase $(p<0.01)$ as well as of the final yield, after purification $(p<0.05)$. Viability of the final preparations was $>85 \%$.

Table 1 Intraepithelial and lamina propria lymphocyte populations determined by immunohistological analysis

\begin{tabular}{|c|c|c|c|c|c|c|c|c|c|}
\hline & \multirow{2}{*}{\multicolumn{2}{|c|}{$\begin{array}{l}\text { HLe-1 }{ }^{+} \\
\% H u T L A^{+}\end{array}$}} & \multirow{2}{*}{\multicolumn{2}{|c|}{$\begin{array}{l}H u T L A^{+} \\
\% O K T 8^{+}\end{array}$}} & \multicolumn{3}{|c|}{ T cells } & \multirow{2}{*}{\multicolumn{2}{|c|}{$\begin{array}{l}\text { OKT8 } \\
\% \mathrm{Leu}^{+} \mathrm{I}^{+}\end{array}$}} \\
\hline & & & & & \multicolumn{2}{|c|}{$\% O K T 8^{+}$} & \multirow[t]{2}{*}{$\% O K T 4^{+}$} & & \\
\hline Intraepithelial lymphocytes & $\mathbf{n}$ & & $\mathbf{n}$ & & $\mathbf{n}$ & & & $\mathbf{n}$ & \\
\hline Controls & 11 & $91 \pm 4 \cdot 9^{*}$ & 5 & $80(72,73,84,86,87)$ & 9 & $86 \pm 10 \cdot 0$ & $14 \pm 10 \cdot 0$ & 9 & $33 \pm 15 \cdot 5$ \\
\hline Ulcerative colitis & 3 & $84(80,85,88)$ & 4 & $80(76,77,82,86)$ & 9 & $83 \pm 10 \cdot 2$ & $17 \pm 10 \cdot 2$ & 10 & $33 \pm 13 \cdot 0$ \\
\hline Crohn's disease & 3 & $90(85,91,95)$ & 3 & $69(44,77,87)$ & 10 & $83 \pm 8 \cdot 9$ & $17 \pm 8 \cdot 9$ & 11 & $37 \pm 14 \cdot 4$ \\
\hline \multicolumn{10}{|l|}{ Lamina propria lymphocytes } \\
\hline Controls & - & & 4 & $41(30,39,39,52)$ & 9 & $32 \pm 8 \cdot 3$ & $68 \pm 8 \cdot 3$ & 9 & $42 \pm 18 \cdot 8$ \\
\hline Ulcerative colitis & - & & 5 & $41(35,38,40,41,50)$ & 9 & $37 \pm 6 \cdot 0$ & $63 \pm 6 \cdot 0$ & 10 & $39 \pm 15 \cdot 1$ \\
\hline Crohn's disease & - & & 3 & $48(39,51,55)$ & 10 & $36 \pm 7 \cdot 0$ & $64 \pm 7 \cdot 0$ & 11 & $40 \pm 13 \cdot 5$ \\
\hline
\end{tabular}

${ }^{*}$ Mean \pm SD. 
Table 2 Yields of mononuclear cells from normal and from diseased intestinal mucosa

\begin{tabular}{|c|c|c|c|c|}
\hline & \multicolumn{2}{|c|}{ Crude yield } & \multicolumn{2}{|l|}{ Final yield } \\
\hline & $\begin{array}{l}\text { No } \\
\left(\times 10^{6} / \mathrm{g}\right)\end{array}$ & $\begin{array}{l}\text { Viability } \\
(\%)\end{array}$ & $\begin{array}{l}\text { No } \\
\left(\times 10^{\circ} / g\right)\end{array}$ & $\begin{array}{l}\text { Viability } \\
\text { (\%) }\end{array}$ \\
\hline \multirow{3}{*}{$\begin{array}{l}\text { Controls } \\
\text { Ulcerative } \\
\text { colitis } \\
\text { Crohn's } \\
\text { disease }\end{array}$} & $18 \pm 8 \cdot 9^{*}$ & $66 \pm 14.9$ & $7 \cdot 7 \pm 5 \cdot 3$ & $90 \pm 8$ \\
\hline & $62 \pm 20+$ & $58 \pm 3$ & $15 \pm 5 \cdot 0 \ddagger$ & $88 \pm 2$ \\
\hline & $55 \pm 16 \dagger$ & $66 \pm 10$ & $16 \pm 8 \cdot 2 \ddagger$ & $89 \pm 4$ \\
\hline
\end{tabular}

* Mean \pm SD. $\dagger \mathrm{p}<0.01 v s$ controls. $\ddagger \mathrm{p}<0.05$ vs controls.

Purification, however, was achieved only at the expense of loss of $60 \%$ of the viable cells.

The lymphocyte subpopulations isolated from the lamina propria are shown in Table 3 . The proportion of $\mathrm{OKT}^{+}$, $\mathrm{T}$ lymphocytes tended to be reduced in ulcerative colitis compared with controls $(\mathrm{p}<0.05)$ with a concomitant increase in $\mathrm{Ig}^{+}$cells $(\mathrm{p}<0.02)$. The proportion of $\mathrm{OKT}^{+}$cells was also reduced in ulcèrative colitis $(p<0 \cdot 02)$. The ratio of $\mathrm{OKT}_{4}{ }^{+}$to $\mathrm{OKT}^{+}$cells, however, did not differ from control values either in ulcerative colitis or Crohn's disease (Fig. 2).

The relative proportions of $\mathrm{OKT}_{4}{ }^{+}$and $\mathrm{OKT} 8^{+}$ lymphocytes in the lamina propria as determined by analysis of tissue sections were different from those obtained in the final gut mucosal cell suspensions, where the ratio of $\mathrm{OKT}_{4}{ }^{+}$to $\mathrm{OKT} 8^{+}$was higher. This reached significance only in patients with Crohn's disease $(p<0.05)$. In eight of the nine subjects (three controls, two patients with ulcerative colitis, and four with Crohn's disease) in whom tissue sections and gut mucosal cells from the same specimen were studied, the $\mathrm{OKT} 4^{+} / \mathrm{OKT} 8^{+}$ratio was higher in the gut mucosal cell population than as determined histologically ( $<<0.02$; Fig. 2 ).

In five subjects studied, the proportion of isolated $\mathrm{OKT}^{+}$cells which were Leu- $1^{+}$was similar to that found in tissue sections $(47+10.6 \%$ vs $45+16.0 \%)$. Of the corresponding peripheral blood $\mathrm{OKT}^{+} \mathrm{T}$ cells, higher proportions were Leu- $1^{+}(65-75 \%)$.

The proportion of $\mathrm{OKT}^{+}$gut mucosal cells that

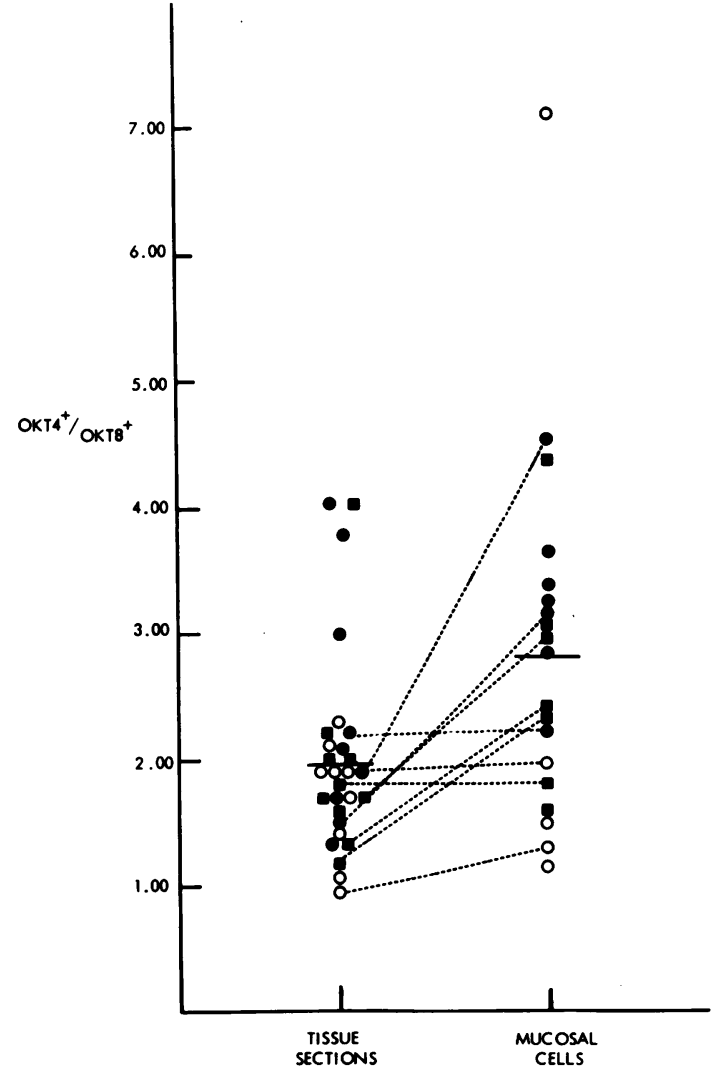

Fig. 2 Ratio of $\mathrm{OKT}^{+}$to $\mathrm{OKT}^{+}$cells determined by analysis of tissue sections or of isolated gut mucosal cells. Broken lines indicate specimens studied by both methods.

were HLA-DR ${ }^{+}$was similar in patient and control groups, with values, except in one patient with ulcerative colitis, of $<10 \%$ (Table 3 ). Similarly, low numbers of $\mathrm{Tac}^{+}$cells were present in the gut mucosal cell populations. The capacity of gut mucosal cell to express these activation antigens was shown in five subjects by culture with optimal concentrations of PHA or Con A. After three days of culture with PHA, an average of $59 \%$ of

Table 3 Lymphocyte populations isolated from intestinal lamina propria

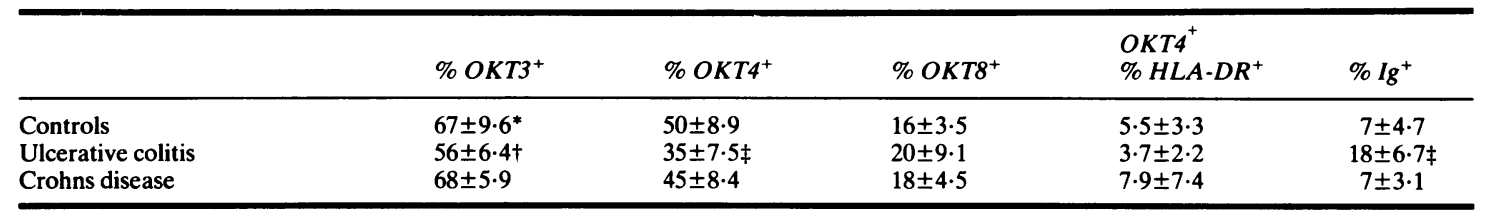

* Mean $\pm \mathrm{SD}+\mathrm{p}<0.05 v s$ controls $\ddagger \mathrm{p}<0.02$ vs controls. 
lymphocytes in the gut mucosal cell population were strongly $\mathrm{Tac}^{+}$(range $29-88 \%$ ). Most of these $\mathrm{Tac}^{+}$ cells had the appearance of lymphoblasts. In addition, $60 \%$ of $\mathrm{OKT}^{+}$cells were also HLA-DR ${ }^{+}$ (19-95\%). With Con $A$, the corresponding values were $41 \%(14-53 \%)$ and $30 \%(4-60 \%)$. Unstimulated gut mucosal cell did not express these antigens.

Treatment of peripheral blood lymphocytes with EDTA after overnight incubation with collagenase did not produce a significant alteration in the $\mathrm{OKT}^{+} / \mathrm{OKT}^{+}{ }^{+}$ratio $(2 \cdot 55+0.82$ vs $2 \cdot 16+0 \cdot 75)$. Similarly, the expression of Tac antigen and of HLA-DR antigens on $T$ lymphocytes was not altered.

\section{Discussion}

In inflammatory bowel disease there is infiltration of the mucosa with lymphocytes, both $T$ cells and $B$ cells. $^{56}$ As shown in this study, however, the proportions of $\mathrm{T}$ lymphocyte subsets, as defined by monoclonal antibodies, do not differ, either in the epithelium or in the lamina propria, from those seen in normal colonic mucosa. This is true both in ulcerative colitis and in Crohn's disease, regardless of disease activity or mode of treatment. These mucosal populations are also similar to those seen in normal small intestine. ${ }^{8}$ The findings indicate that the pathogenesis of inflammatory bowel disease does not depend upon an imbalance of the immunoregulatory $\mathrm{T}$ cells defined by the monoclonal antibodies used in this study. They also suggest that the reduction in the number of circulating $\mathrm{T}$ lymphocytes seen in patients with inflammatory bowel disease, without alteration in the proportions of $\mathrm{T}$ cell subsets, ${ }^{4}$ may well be because of sequestration into involved mucosa. This emphasises the need to study events in the mucosa rather than those in the peripheral blood.

These results are in contrast with those seen in the delayed type hypersensitivity response to soluble antigen in the skin, where there is infiltration with Leu- $3^{+}\left(\mathrm{OKT}_{4}{ }^{+}\right)$cells $^{19}$ and with those in rheumatoid arthritis, where there is a similar excess of $\mathrm{OKT}^{+}{ }^{+}$cells in the synovial membrane, and this may play a role in the excess immunoglobulin production characteristic of that disorder. ${ }^{20}$ In sarcoidosis, with high intensity alveolitis, pulmonary aspirates contain an excess of $\mathrm{OKT} 4^{+}$cells. ${ }^{21}$ In graft $v s$ host disease and in chronic hepatitis $\mathrm{B}$, on the other hand, infiltrating $\mathrm{T}$ cells are $\mathrm{OKT} 8^{+} .1622$ Our findings differ from those seen in adult coeliac disease where there is an increase in $\mathrm{OKT}^{+}$ Leu- ${ }^{+}$cells within the epithelium and lamina propria, which is thought to reflect increased traffic of a distinct $\mathrm{T}$ cell population through the mucosa. ${ }^{8}$

Although intestinal $\mathrm{T}$ lymphocyte subsets are unaltered in inflammatory bowel disease, immune mechanisms within the mucosa still appear to be important. Evidence for this comes from the increase within the mucosa of HLA-DR ${ }^{+}$, macrophage-like cells, which have features suggestive of activation ${ }^{23}$ and from the expression of HLA-DR antigens by colonic epithelial cells in active disease, suggesting that the epithelium may be altered in an immune response, perhaps due to the effects of intraepithelial lymphocytes (Selby et al). ${ }^{8}$

Techniques recently developed have allowed the isolation of mononuclear cell populations from human intestinal mucosa. ${ }^{9}{ }^{24}$ The proportion of $T$ lymphocytes, determined using sheep red cell rosetting techniques, obtained from colonic lamina propria by such methods has been extremely variable, ranging from 34 to $92 \% .^{925-30}$ This variability is similar to that found in studies of circulating $\mathrm{T}$ lymphocytes, and may reflect differences in methodology as well as the effects of the isolation procedure. In the only previous study of $T$ lymphocyte subpopulations isolated from intestinal lamina propria, ReMine $e t a l^{31}$ found that $13 \%$ of E-rosetting lymphocytes in gut mucosal cell populations had $\mathrm{Fc}$ receptors for $\mathrm{IgG}$ ( $\mathrm{T}_{\mathrm{G}}$ cells). This proportion was reduced in patients with active inflammatory bowel disease $(8 \%)$. These cells were originally thought to represent the suppressor subset of T lymphocytes, but this no longer appears to be true. ${ }^{32}$

The present study confirms the work of others ${ }^{925}$ showing that the majority of lymphocytes isolated from the lamina propria of normal intestine are $T$ cells $\left(\mathrm{OKT}^{+}\right)$. In inflamed mucosa, the number of lymphocytes, and of $\mathrm{T}$ lymphocytes, isolated was two to three times greater than from normal intestine. The proportions of $T$ lymphocyte subsets obtained by analysis of isolated gut mucosal cell populations, however, did not always match those obtained by immunohistological analysis. In particular, tissue section studies either underestimated the proportion of $\mathrm{OKT}_{4}^{+}$cells, or the isolation procedure led to a relative depletion of $\mathrm{OKT}^{+}$cells, leading to higher $\mathrm{OKT}^{+} / \mathrm{OKT}^{+}$ ratios in the gut mucosal cell suspensions. The latter explanation seems more likely. The proportions of $T$ cell subsets analysed using three different double combinations of antibodies on tissue sections were similar (R anti-HuTLA and OKT8; OKT4 and OKT8; anti-Leu-1 and OKT8). The isolation of gut mucosal cells involves considerable manipulation of tissue and of cell populations, and the populations 
obtained represent only a proportion of those in the mucosa, with cells being lost during dissection, mincing, washing, incubation, and purification. ${ }^{33}$ The reason for a selective depletion of $\mathrm{OKT}^{+}$cells in some cases is unclear.

Disparity between histological findings and isolated gut mucosal cell populations has been reported previously, but not emphasised. For example, although in most studies the increase in the number of mucosal lymphocytes in inflammatory bowel disease has been reflected by an increase in the number of isolated cells ${ }^{29} 3435$ this has not been the case in all. ${ }^{36}{ }^{37}$ Similarly, although plasma cells are as numerous as lymphocytes in the colonic mucosa, ${ }^{38}$ very few of these cells are obtained in the gut mucosal cell populations isolated from either normal or diseased mucosa. ${ }^{28}{ }^{34}{ }^{39}$ Nevertheless, the ability to isolate mucosal cell populations enables an assessment of their functions in vitro. Cells isolated from normal intestine have been shown to be capable of responding to non-specific mitogens as well as to bacterial antigens, ${ }^{24} 27283536$ of immunoglobulin synthesis and antibody production, ${ }^{27} 4041$ suppressor activity, ${ }^{27} 37$ and mitogen induced $\mathrm{T}$ cell cytotoxicity. ${ }^{10} 3033$ In the peripheral blood these are functions of, or are regulated by, $\mathrm{OKT}_{4}{ }^{+}$and $\mathrm{OKT}^{+}$populations, suggesting that mucosal $\mathrm{T}$ lymphocyte populations may act locally in a manner similar to peripheral blood $\mathrm{T}$ cells. One major difference, however, has been the observation that mucosal $T$ cells can respond to an allogeneic stimulus, but are unable to act as effector $T$ cells mediating lysis of the stimulating cells. ${ }^{10}$ In the blood, the former is a property of $\mathrm{OKT}_{4}{ }^{+}$and $\mathrm{OKT}^{+}$cells, whereas cytotoxicity is confined to the $\mathrm{OKT}^{+}$population. ${ }^{15}$ Although an absence of $\mathrm{OKT}^{+}\left(\mathrm{TH}_{2}{ }^{+}\right) \mathrm{T}$ cells in the intestinal mucosa was proposed as one explanation for this phenomenon, the demonstration of these cells in tissue sections and isolated gut mucosal cells suggests that intestinal mucosal $\mathrm{OKT}^{+}$cells may function in a different way from those in the circulation. The variable expression of Leu-1 on $\mathrm{OKT}^{+}$cells may be important in this respect.

Functional studies of gut mucosal cells in inflammatory bowel disease have so far yielded varying and often conflicting results in terms of mitogen responsiveness, which may be normal, ${ }^{35}$ reduced, ${ }^{36}$ or increased, ${ }^{37}$ suppressor cell function ${ }^{27} 37$ and immunoglobulin production. ${ }^{34} 40$ This variability has been attributed to the effects of the isolation procedure on cell function, ${ }^{25}{ }^{33}$ but may also be due to the variation in the proportion of $T$ lymphocytes and $\mathrm{T}$ lymphocyte subsets isolated. As shown in this study, these may not always be representative of those present in the tissue.
The phenotypic markers of $\mathrm{T}$ cell activation, HLA-DR and Tac antigens, were found on only small proportions of $\mathrm{T}$ lymphocytes isolated from normal or from inflamed mucosa. Mucosal lymphocytes, however, are able to express these antigens when stimulated in vitro. This suggests that, by these criteria, only a small proportion of $\mathrm{T}$ lymphocytes are activated in the tissue. Fiocchi et al ${ }^{35}$ showed that the proportion of activated $\mathrm{T}$ cells, forming stable rosettes with sheep red cells at $37^{\circ} \mathrm{C}$, was not increased in mucosal cells isolated from patients with Crohn's disease. After culture, however, the number of activated cells increased rapidly, without stimulation. Expression of HLA-DR and Tac antigens was not seen on unstimulated gut mucosal cells during culture in this study.

Increasing attention is being paid to the role of mucosal, rather than circulating, lymphocyte subpopulations in the pathogenesis of intestinal diseases such as inflammatory bowel disease. Study of tissue sections enables analysis of cell populations and their interactions in situ, as well as examination of the local microenvironment. The ability to isolate mucosal cell populations, both from the epithelium ${ }^{33} 39$ and from the lamina propria, allows study of their function. The isolation procedures, however, may not result in truly representative populations, and thus it is vital to continue to assess functional studies of intestinal lymphocytes in combination with histological analysis. Only such a combined approach will increase our understanding of the role of the intestinal immune system in health and disease.

WSS was in receipt of the Pharmacia Fellowship. MB was supported by a British Council Scholarship. We wish to thank the following colleagues for the gift of monoclonal antibodies: Dr P Beverley (2D1 and UCHT1); Dr G Goldstein (OKT3, OKT4, and OKT8); Drs D Y Mason and H Stein (C3RT05); and Dr T Waldmann (anti-Tac).

\section{References}

$1 \mathrm{Kraft}$ SC. Inflammatory bowel disease (ulcerative colitis and Crohn's disease). In: Asquith P, ed. Immunology of the gastrointestinal tract. Edinburgh: Churchill Livingstone, 1979: 95-128.

2 Hodgson HJF, Wands JR, Isselbacher KJ. Decreased suppressor cell activity in inflammatory bowel disease. Clin Exp Immunol 1978; 32: 451-8.

3 Victorino RMM, Hodgson HJF. Spontaneous suppressor cell function in inflammatory bowel disease. Dig Dis Sci 1981; 26: 801-6. 
4 Selby WS, Jewell DP. T lymphocyte subsets in inflammatory bowel disease: peripheral blood. Gut 1983; 24: 106-13.

5 Strickland RG, Husby G, Black WC, Williams RC Jr. Peripheral blood and intestinal lymphocyte subpopulations in Crohn's disease. Gut 1975; 16: 847-53.

6 Meuwissen SGM, Feltkamp-Vroom TM, Brutel de la Riviere A, Von Dem Borne AEG, Tytgat GN. Analysis of the lympho-plasmacytic infiltrate in Crohn's disease with special reference to identification of lymphocyte-subpopulations. Gut 1976; 17: 770-80.

7 Selby WS, Janossy G, Goldstein G, Jewell DP. T lymphocyte subsets in normal intestinal mucosa - the distribution and relationship to MHC-derived antigens. Clin Exp Immunol 1981; 44: 453-8.

8 Selby WS, Janossy G, Bofill M, Jewell DP. Lymphocyte subpopulations in the human small intestine. The findings in normal mucosa and in the mucosa of patients with adult coeliac disease. Clin Exp Immunol 1983. (In press.)

9 Bull DM, Bookman MA. Isolation and functional characterisation of human intestinal mucosal lymphoid cells. J Clin Invest 1977; 59: 966-74.

10 MacDermott RP, Franklin GO, Jenkins KM, Kodner IJ, Nash GS, Weinrieb IJ. Human intestinal mononuclear cells. I. Investigation of antibody-dependent, lectin-induced, and spontaneous cell-mediated cytotoxic capabilities. Gastroenterology 1980; 78: 4756.

11 Lampert IA, Janossy G, Suitters A et al. Immunological analysis of the skin in graft versus host disease. Clin Exp Immunol 1982; 50: 123-31.

12 Beverley PCL. Production and use of monoclonal antibodies in transplantation immunology. In: Proceedings of the IXth International Course of Transplantation and Clinical Immunology. Amsterdam: Elsevier, 1980.

13 Beverley PCL, Callard RE. Distinctive functional characteristics of human ' $T$ ' lymphocytes defined by $E$ rosetting or a monoclonal anti-T cell antibody. Eur $J$ Immunol 1981; 11: 329-34.

14 Martin PJ, Hansen JA, Siadak AW, Nowinski RC. Monoclonal antibodies recognising human $\mathrm{T}$ lymphocytes and malignant human $B$ lymphocytes: a comparative study. J Immunol 1981; 127: 1920-3.

15 Reinherz EL, Schlossman SF. The differentiation and function of human T lymphocytes. Cell 1980; 19: 821-7.

16 Janossy G, Montano L, Selby WS et al. T cell subset abnormalities in tissue lesions developing during autoimmune disorders, viral infection and graft versus host disease. J Clin Immunol 1982; 2: 42S-56S.

17 Uchiyama T, Broder S, Waldmann TA. A monoclonal antibody (anti-Tac) reactive with activated and functionally mature human T cells. I. Production of anti-Tac monoclonal antibody and distribution of Tac(+) cells. J Immunol 1981; 126: 1393-7.

18 Gerdes J, Naiem M, Mason DY, Stein H. Human complement receptors defined by a mouse monoclonal antibody. Immunology 1982; 45: 645-53.

19 Scheynius A, Klareskog L, Forsum U. In situ identification of $T$ lymphocyte subsets and HLA-DR expressing cells in the human skin tuberculin reaction.
Clin Exp Immunol 1982; 49: 325-30.

20 Janossy G, Panayi G, Duke O, Bofill M, Poulter LW, Goldstein G. Rheumatoid arthritis: a disease of $T$ lymphocyte/macrophage immunoregulation. Lancet 1981; 2: 839-42.

21 Hunninghake GW, Crystal RG. Pulmonary sarcoidosis. A disorder mediated by excess helper T-lymphocyte activity at sites of disease activity. $N$ Engl J Med 1981; 305: 429-34.

22 Eggink HF, Houthoff $\mathrm{HJ}$, Huitema S, Gips $\mathrm{CH}$, Poppema S. Cellular and humoral immune reactions in chronic active liver disease. I. Lymphocyte subsets in liver biopsies of patients with untreated idiopathic autoimmune hepatitis, chronic active hepatitis $B$ and primary biliary cirrhosis. Clin Exp Immunol 1982; 50: 17-24.

23 Selby WS, Poulter LW, Hobbs S, Jewell DP, Janossy G. Heterogeneity of HLA-DR-positive histiocytes in human intestinal lamina propria: a combined histochemical and immunohistological analysis. $J$ Clin Pathol 1983; 36: 379-84.

24 Clancy $R$. Isolation and kinetic characteristics of mucosal lymphocytes in Crohn's disease. Gastroenterology 1976; 70: 177-80.

25 Bland PW, Richens ER, Britton DC, Lloyd JV. Isolation and purification of human large bowel mucosal lymphoid cells: effect of separation technique on functional characteristics. Gut 1979; 20: 1037-46.

26 Chiba M, Shorter RG, Thayer WR, Bartnik W, ReMine S. $\mathrm{K}$ cell activity in lamina proprial lymphocytes from the human colon. Dig Dis Sci 1979; 24: 817-22.

27 Fiocchi C, Battisto JR, Farmer RG. Gut mucosal lymphocytes in inflammatory bowel disease. Isolation and preliminary functional characterisation. Dig Dis Sci 1979; 24: 705-17.

28 Goodacre R, Davidson R, Singal D, Bienenstock J. Morphological and functional characteristics of human intestinal lymphoid cells isolated by a mechanical means. Gastroenterology 1979; 76: 300-8.

29 Eade OE, Standre-Ukena S, Moulton C, Macpherson B, Beeken WL. Lymphocyte subpopulations of intestinal mucosa in inflammatory bowel disease. Gut 1980; 21: 675-82.

30 Falchuk ZM, Barnhard E, Machado I. Human colonic mononuclear cells: studies of cytotoxic function. Gut 1981; 22: 290-4.

31 ReMine SG, Bartnik W, Bahn RC, Shorter RG. Further characterisation of lymphocytes from human colonic lamina propria: identification of $\mathrm{T}_{\mathbf{G}}$ cells. Clin Exp Immunol 1981; 46: 294-300.

32 Reinherz EL, Moretta L, Roper $M$ et al. Human $T$ lymphocyte subpopulations defined by $\mathrm{Fc}$ receptors and monoclonal antibodies. A comparison. J Exp Med 1980; 151: 969-74.

33 Chiba M, Bartnik W, ReMine SG, Thayer WR, Shorter RG. Human colonic intraepithelial and lamina proprial lymphocytes: cytotoxicity in vitro and the potential effects of the isolation method on their functional properties. Gut 1981; 22: 177-86.

34 Bookman MA, Bull DM. Characteristics of isolated intestinal mucosal lymphoid cells in inflammatory 
bowel disease. Gastroenterology 1979; 77: 503-10.

35 Fiocchi C, Battisto JR, Farmer RG. Studies on isolated gut mucosal lymphocytes in inflammatory bowel disease. Detection of activated $\mathrm{T}$ cells and enhanced proliferation to staphylococcus aureus and lipopolysaccharides. Dig Dis Sci 1981; 26: 728-36.

36 MacDermott RP, Bragdon MJ, Jenkins KM. Human intestinal mononuclear cells. II. Demonstration of a naturally-occurring subclass of $T$ cells which respond in the allogeneic mixed leukocyte reaction but do not affect cell-mediated lympholysis. Gastroenterology 1981; 80: 748-57.

37 Goodacre RL, Bienenstock J. Reduced suppressor cell activity in intestinal lymphocytes from patients with Crohn's disease. Gastroenterology 1982; 82: 653-8.

38 Ginsel LA, Liepman HP, Weterman IT. Light- and electronmicroscopical studies on the distribution of various cell types in the sigmoid colon of normal subjects and in patients with Crohn's disease. In: Pena AS, Weterman IT, Booth CC, Strober W, eds. Recent advances in Crohn's disease. Recent developments in gastroenterology, vol 1. The Hague: Martinus Nijhoff, 1981: 124-30.

39 Bartnik W, ReMine SG, Chiba M, Thayer WR, Shorter RG. Isolation and characterisation of colonic intraepithelial and lamina proprial lymphocytes. Gastroenterology 1980; 78: 976-85.

40 MacDermott RP, Nash GS, Bertovich MJ, Seiden MV, Bragdon MJ, Beale MG. Alterations of IgM, IgG and IgA synthesis and secretion by peripheral blood and intestinal mononuclear cells from patients with ulcerative colitis and Crohn's disease. Gastroenterology 1981; 81: 844-52.

41 Heddle RJ, LaBrooy JT, Shearman DJC. Escherichia coli antibody-secreting cells in the human intestine. Clin Exp Immunol 1982; 48: 469-76. 